\title{
ISU DAN TANTANGAN KOMPETENSI DEWAN PENGAWAS SYARIAH DI INDONESIA
}

\author{
Nadia Farhana Izzatika dan Ahmad Tarmidzi Lubis \\ Program Studi Akuntansi Syariah \\ Sekolah Tinggi Ekonomi Islam SEBI \\ Email: enadnadiafarhana13@gmail.com
}

\begin{abstract}
This study aims to discover and know the issues and challenges the competence of the shariah supervisory board in Indonesia. Given the inequality between sharia accounting competence. The discussion of this study will combine engineering library research with interviews with practitioners and academics who work in auditing sharia. The results of this study discovered that there are three issues related to the competence of shariah supervisory board in Indonesia, which is, 1) Unbalance the competency of the shariah supervisory board in accounting and finance with competence in the field of sharia, 2) Certification shariah supervisory board in Indonesia has not been optimal, 3) Still lack a college that provides programs of study sharia accounting so that the shariah supervisory board there is still limited. Referring to the issue of the things that are a challenge related to the competence of auditors of sharia in Indonesia, which is, In terms of the challenges of 1) Upgrading the competence of the shariah supervisory board, 2) Cooperation between DSN-MUI with the FSA in creating shariah supervisory board certification, 3) Educational institutions are able to meet the needs of related industries shariah supervisory board.
\end{abstract}

Keywords: competence, Shariah Supervisory Board; Islamic financial institution

\section{PENDAHULUAN}

Pertumbuhan dan perkembangan lembaga keuangan syariah secara nasional mengalami peningkatan yang begitu pesat kurang lebih dua dekade yang lalu. Menurut Statistik Perbankan Syariah per Juni 2015 mencatat bahwa jumlah Bank Umum Syariah (BUS) sebanyak 12 bank, Unit Usaha Syariah (UUS) sebanyak 22, Bank Pengkreditan Rakyar Syariah (BPRS) sebanyak 161 bank dan jaringan kantor sebanyak 2888, hal ini mencerminkan tren peningkatan yang cukup positif. Sejalan dengan itu, jika dilihat dari sisi pertumbuhan total Aset, Pembiayaan, dan Dana Pihak Ketiga (DPK) perbankan syariah khususnya Bank Umum Syariah (BUS) dan Unit Usaha Syariah (UUS) mengalami peningkatan yang baik dari tahun ke tahunnya.

Disamping itu, optimisme dunia internasional terhadap keuangan syariah Indonesia tergolong cukup tinggi. Hal tersebut dikukung oleh penilaian Ernst \& Young dalam World Islamic Banking Competitives Report 2013-2014 maupun UK's Global Islamic Finance Report 2013 bahwa keuangan syariah Indonesia adalah termasuk kedalam rapid growth market dan dynamic market, serta telah menjadi referensi pengembangan keuangan 
syariah maupun berpotensi sebagai salah satu pendorong keuangan syariah dunia (OJK, 2013).

Sebagai lembaga keuangan syariah, bank syariah juga harus memastikan bahwa produk, jasa, dan operasional perusahaannya telah sesuai dengan prinsip-prinsip syariah guna mempertanggungjawabkan usahanya kepada para stakeholder. Menurut Hassan (2010), setiap lembaga keuangan syariah khususnya perbankan syariah harus memiliki model tata kelola yang handal dan strategi yang tepat yang akan mendorong pelaksanaan tata kelola perusahaan yang kuat dan efektif dalam lingkungan syariah. Kepatuhan syariah termasuk kepada persoalan yang utama dalam tata kelola bank syariah, karena kepatuhan syariah merupakan pilar utama dan pembeda lembaga keuangan syariah dengan lembaga keuangan konvensional.

Kebutuhan atas kepastian pemenuhan syariah ini mendorong munculnya fungsi audit baru, yaitu audit syariah. Hal ini didukung oleh Yaqoob \& Donglah (2012) yang menyatakan bahwa dalam mempertimbangkan pesatnya pertumbuhan industri syariah, sangat penting untuk lembaga keuangan syariah untuk memiliki check and balance yang memadai mengenai mekanisme dalam bentuk audit syariah yang sesuai dengan tujuan dan misi dari maqasid al-shariah.

Dengan adanya audit shariah untuk lembaga keuangan syariah memberikan jaminan dan akuntabilitas yang independen kepada para pemegang saham mengenai hal-hal yang berkaitan dengan operasi lembaga keuangan syariah berdasarkan prinsip syariah. Dalam hal ini, auditor syariah memegang peran krusial di mana bukan hanya harus memastikan akuntabilitas dari laporan keuangan yang dibuat oleh lembaga keuangan syariah tetapi juga harus dapat memastikan aspek syariah telah terpenuhi dengan sempurna.

Namun dalam penerapannya audit syariah memiliki tantangan tersendiri. Menurut Kasim, Ibrahim, \& Sulaiman (2009) bahwa ada gap antara harapan dan praktik audit syariah yang berlangsung saat ini. Setidaknya ada 4 faktor utama yang menjadi kendala besar penerapan audit yang berdasarkan hukum syariah tersebut, yaitu kerangka kerja, ruang lingkup, kompetensi auditor syariah dan isu terkait independensi. Hampir disemua negara yang mengembangkan lembaga keuangan syariah mengalami 4 faktor kendala tersebut.

Lebih lanjut, apabila dilihat secara terpisah dan mendalam sumber permasalahan audit syariah yaitu diprioritaskan pada aspek kompetensi auditor syariah, karena melihat betapa beratnya baik ditinjau secara moril maupun materil maka sebaiknya audit harus dilakukan oleh seorang yang kompeten dan independen. Khan (1985) mengungkapkan bahwa kefasihan pada bahasa arab dan inggris serta pemahaman dengan pengetahuan yang baik dalam syariah, fiqh mu'amalah, akuntansi, keuangan, audit dan bisnis dapat membantu auditor syariah dalam meningkatkan kompetensinya dan meningkatkan pemahaman terhadap kepatuhan syariah. Ia berpendapat bahwa karena lembaga keuangan syariah beroperasi di bawah platform yang 
berbeda yaitu dengan pandangan dunia Islam, mereka mungkin memerlukan berbagai jenis akuntansi dan audit yang berbeda.

Berkaitan dengan kompetensi auditor syariah, masih terdapat dikotomi atau ketimpangan kompetensi antara syariah dan akuntansi. Kasim, Ibrahim, \& Sulaiman (2009) mengungkapkan bahwa

Auditor syariah yang menguasai ilmu syariah dan ilmu akuntansi hanya $5,9 \%$ dari total responden. Adapun keseluruhan responden tersebut mencerminkan $68 \%$ dari keseluruhan auditor syariah yang terdapat pada lembaga keuangan syariah di Malaysia. Hasil tersebut juga menunjukan adanya korelasi negatif antara orang-orang yang menguasai akuntansi dengan orang yang menguasai syariah. Artinya semakin tinggi orang yang menguasai akuntansi maka semakin rendah penguasaannya terhadap syariah, begitupun sebaliknya. (hal. 135).

Ketimpangan kompetensi ini juga ditemukan di Bahrain oleh Hood \& Bucheery (1999) yang dikutip oleh Shafii, et. al (2013), penelitian tersebut menemukan bahwa ketidaksesuaian antara harapan dan realita yang terjadi karena belum memadainya pemahaman auditor syariah yang terlihat dari audit syariah yang hanya difungsikan sebagai pelengkap dari audit keuangan. Selain itu, juga belum ditemukan opini dari audit syariah seperti layaknya audit keuangan dari auditor independen.

Di Indonesia sendiri, praktisi audit di Indonesia ini masih mencari pedoman aturan yang tepat, regulasi kerangka kerja, serta kompetensi dan independensi auditor syariah (Shafii, et. al, 2013). Pendapat tersebut didukung oleh penelitian Akbar (2015) bahwa ada dua permasalahan terkait kompetensi auditor syariah, pertama dari sisi kualitas yaitu tidak seimbangnya kompetensi auditor syariah dalam pengetahuan akuntansi dan syariah. Kedua, dari sisi kuantitas yaitu masih terbatasnya jumlah auditor syariah yang dimiliki oleh Indonesia. Sebagai negara dengan mayoritas penduduknya adalah muslim, jumlah auditor syariah yang dimiliki masih sangat terbatas.

Dengan demikian, hal tersebut menjadi permasalahan dan tantangan yang serius bagi auditor syariah khususnya dewan pengawas syariah di Indonesia. belum lagi jika ditinjau dari segi keilmuan kompetensi yang harus dimiliki oleh auditor syariah berbeda dengan auditor pada umumnya karena auditor harus mengkombinasikan aspek keuangan dan aspek syariah dari operasional perusahaan. Akan tetapi, kompetensi yang dimiliki oleh auditor syariah terhadap pengetahuan syariah dan akuntansi relatif belum memadai, lembaga pendidikan yang menghasilkan sumber daya manusia yang berkompetensi dalam audit syariah juga masih minim, karena bagaimanapun pendidikan di bidang syariah, akuntansi dan auditing sangat penting untuk meningkatkan kompetensi (pengetahuan dan keahlian) seorang auditor syariah. Selain itu juga, karena kurangnya pemahaman auditor syariah menjadikan audit syariah yang hanya difungsikan sebagai pelengkap dari audit keuangan.

Hal inilah yang mendasari perlu adanya kajian lebih mendalam melalui penelitian tentang isu dan tantangan kompetensi dewan pengawas 
syariah di Indonesia. Pembahasan kajian ini akan menggabungkan teknik penelitian kepustakaan (library research), menemukan teori-teori yang relevan, kemudian digabungkan dengan wawancara bersama praktisi dan akademisi yang berkiprah di dunia auditing syariah.

\section{TELAAH LITERATUR}

\subsection{AUDIT SYARIAH}

Haniffa (2010) dan Sultan (2007), mendefinisikan audit syariah sebagai sebuah proses pemeriksaan sistematis atas kepatuhan seluruh aktivitas lembaga keuangan syariah terhadap prinsip syariah, khususnya laporan keuangan dan komponen operasi lainya dari lembaga keuangan syariah yang memiliki resiko kepatuhan tersebut dan tidak terbatas hanya pada produk tetapi juga penggunaan IT, proses operasi, pihak - pihak yang terlibat dalam aktivitas bisnis lembaga keuangan syariah, dokumentasi dan kontrak, kebijakan dan prosedur serta aktivitas lainnya yang memerlukan ketaatan terhadap prinsip syariah.

Menurut AAOIFI's Governance Standard Islamic Financial Institution No.2 (GSIFI 2) diartikan sama dengan sharia review yang dijalankan oleh departemen atau bagian dari audit internal yaitu memeriksa dan mengevaluasi tingkat kepatuhan terhadap aturan syariah, fatwa, aturan dan sejenisnya yang dikeluarkan oleh bagian fatwa dan dewan pengawas syariah yang independen (Sultan, 2007, hal. 6).

Penerapan audit syariah ini termasuk ketaatan kepada Allah sebagai upaya untuk mengusahakan kebaikan dan menghindarkan diri dari kedzoliman dan keburukan. Adapun dalil yang meligitimasi pelaksanaan audit syariah terkandung pada ayat berikut ini:

Artinya: "Hai orang-orang yang beriman, jika datang kepadamu orang fasik membawa suatu berita, maka periksalah dengan teliti agar kamu tidak menimpakan suatu musibah kepada suatu kaum tanpa mengetahui keadaannya yang menyebabkan kamu menyesal atas perbuatan itu." (Q.S. Al Hujurat [49]:6)

Berdasarkan ayat diatas, pemeriksaan untuk mendapatkan kebenaran dikenal dengan istilah tabayyun dimana hukumnya wajib terhadap golongan yang fasik. Ayat ini menunjukan pentingnya pemeriksaan secara teliti atas sebuah informasi karena bisa menjadi penyebab terjadinya musibah atau bencana. Dalam konteks audit syariah, pemeriksaan dilakukan terhadap daftar keuangan untuk mendapat kepastian agar penyajiannya wajar atau tidak menyesatkan para pengguna laporan keuangan dalam pengambilan keputusan yang akhirnya diharapkan menghindari musibah yang salah satunya berupa krisis keuangan.

Komitmen dan konsistensi terhadap prinsip syariah yang tercermin dalam akad, produk, operasional lembaga keuangan syariah menjadi hal utama yang harus dicapai dalam pelaksanaan audit syariah karna termasuk 
kedalam penjagaan islam itu sendiri. Oleh karena itu, tujuan utama audit syariah yaitu untuk memastikan kepatuhan lembaga keuangan syariah terhadap prinsip keuangan syariah.

Menurut AAOIFI's Auditing Standard For Islamic Financial Institution No.1 (ASIFI 1) tujuan utama auditing dalam lembaga keuangan syariah, secara garis besar adalah untuk memberikan opini atas laporan keuangan yang disiapkan manajemen (perusahaan), dalam semua aspek material telah sesuai dengan hukum dan prinsip syariah, standar AAOIFI, dan standar akuntansi nasional negara bersangkutan. Sehingga audit syariah ini memiliki tujuan yang lebih luas dari audit keuangan dimana auditor juga harus membuktikan bahwa manajemen telah memenuhi maqashid syariah. Dengan kata lain audit dalam lembaga keuangan syariah tidak hanya terbatas pada peraturan umum audit financial tetapi juga pandangan syariah (Haniffa, 2010, hal. 3-4).

\subsection{AUDITOR SYARIAH}

Istilah auditor syariah dimunculkan untuk menyesuaikan dengan operasional entitas syariah dimana proses audit tidak hanya dilakukan berdasarkan standar regulasi tetapi juga standar atau prinsip syariah (Mardian, 2013, hal. 179-180). Menurut Haniffa (2010) auditor syariah tidak secara tegas dimaksudkan hanya untuk auditor independen yang tergabung dikantor akuntan publik melainkan pihak yang bisa menjalankan fungsi audit syariah. Pemain kunci yang terlibat dalam audit syariah dalam sebuah entitas dengan perannya masing-masing yaitu auditor eksternal, Dewan Pengawas Syariah, auditor internal, komite audit dan divisi tata kelola (hal. 2).

\subsubsection{Dewan Pengawas Syariah}

Dewan Pengawas Syariah merupakan pihak yang memainkan peran kunci dalam kesuluran audit dan kerangka tata kelola perusahaan dalam lembaga keuangan syariah. Dewan Pengawas Syariah juga berperan untuk merumuskan kebijakan dan pedoman yang harus diikuti oleh manajemen dalam kegiatan mereka, termasuk persetujuan atas produk yang dikeluarkan dan juga melakukan shariah review, yang merupakan pemeriksaan untuk memastikan bahwa kegiatan yang dilakukan oleh lembaga keuangan syariah tidak bertentangan dengan prinsip-prinsip syariah (Haniffa, 2010).

\subsubsection{Karakteristik Auditor Syariah diluar Dewan Pengawas Syariah}

Menurut Haniffa (2010, hal. 2-4) menyebutkan peran yang dimainkan oleh key player yang terlibat dalam audit syariah diluar dewan pengawas syariah adalah sebagai berikut:

\section{Auditor Eksternal}

Auditor eksternal memiliki peran yang unik dalam audit syariah, bukan hanya berperan dalam melakukan audit keuangan tetapi juga melakukan shariah compliance test untuk memastikan kepatuhan syariah dari perusahaan atau lembaga keuangan syariah. Proses audit tersebut 
dilakukan secara terstruktur, dimulai dengan perencanaan audit dan diakhir dengan pemberian opini oleh auditor terkait laporan keuangan yang disiapkan telah sesuai fatwa, pedoman yang digunakan oleh Dewan Pengawas Syariah, standar dari AAOIFI, serta standar dan praktik akuntansi yang berlaku dalam negeri yang bersangkutan. Di sisi lain, untuk perihal penilaian shariah compliance dalam pengukura aturan dan prinsip syariah disesuaikan dengan aturan dan arahan yang telah ditentukan oleh Dewan Pengawas Syariah setiap lembaga keuangan syariah.

\section{Auditor Internal}

Ruang lingkup tugas dan peran yang dilakukan oleh auditor internal meliputi pemeriksaan dan evaluasi atas kecukupan dan efektivitas sistem pengendalian internal dan kualitas suatu kinerja sebagaimana terlihat berikut ini:

a. Menelaah keandalan dan integritas informasi keuangan dalam suatu operasi.

b. Meninjau dan menjaga aset bahkan jika perlu memverifikasi keberadaan aset tersebut.

c. Meninjau sistem yang dibentuk untuk memastikan kepatuhan terhadap kebijakan-kebijakan, prosedur, rencana peraturan dan hukum.

d. Menilai sisi ekonomi dan efisiensi mengenai sumber daya yang digunakan

e. Meninjau operasi atau program untuk memastikan apakah hasil yang konsisten dengan tujuan yang ditetapkan dan apakah operasi atau program yang sedang dilaksanakan seperti yang direncanakan.

\section{Komite Audit dan Tata Kelola}

Peran auditor kepatuhan diungkapkan melalui GSIFI no 4 yaitu bertanggung jawab untuk memeriksa struktur dan proses pengendalian internal dan memastikan bahwa kegiatan lembaga keuangan syariah sesuai dengan prinsip syariah. Tugas ini juga mencakup review terhadap laporan yang dihasilkan auditor internal yang melakukan sharia review sebelumnya dan juga terhadap Dewan Pengawas Syariah guna memastikan bahwa mereka telah mengambil keputusan yang tepat.

\subsection{KOMPETENSI}

Kompetensi merupakan landasan dasar karakteristik seseorang yang mengindikasikan cara berperilaku atau berfikir, menyamakan situasi dan mendukung untuk periode waktu yang cukup lama. Faktor yang mempengaruhi kecakapan kompetensi seseorang yaitu keyakinan dan nilai- 
nilai, keterampilan, karakteristik kepribadian, motivasi, isu emosional, kemampuan intelektual dan budaya organisasi (Spencer \& Spencer, 1993).

Dilihat dari disiplin perilaku organisasi, kompetensi bersama dengan komitmen termasuk pada kelompok faktor karakteristik individu anggota organisasi. Para ahli perilaku organisasi seperti Kreitner \& Kinicki (2003), konsep kompetensi dipahami sebagai gabungan dari kemampuan dan keterampilan. Kemampuan menunjukkan karakteristik stabil yang berkaitan dengan kemampuan maksimum fisik dan mental seseorang. Keterampilan di sisi lain adalah kapasitas khusus untuk memanipulasi suatu objek.

Adapun kompetensi yang harus dimiliki auditor syariah adalah sebagai berikut:

Tabel 1. Kompetensi Auditor Syariah

No Kompetensi yang harus dimiliki auditor syariah

1. Memiliki keterampilan,sikap dan pengetahuan di bidang akuntansi atau auditing

2. Memiliki pengetahuan syariah terkait prinsip dan hukum Islam, khususnya pada Fiqh Muamalat

3. Memiliki pemahaman yang kuat tentang As-Sunnah dan ilmu fiqh islam seperti ushul fiqh

Memahami standar akuntansi internasional yang diadopsi dengan

4. standar akuntansi dan auditing yang berlaku didalam wilayah nasional.

4. Serta standar yang diadopsi oleh negara-negara muslim lain jika mereka ingin bekerja di negara lain yang telah menerapkan audit syariah.

5. Kefasihan dalam berbahasa arab dan inggris

6. Memiliki pemahaman dengan pengetahuan yang baik dalam bidang keuangan dan bisnis

7. Memahami teori dan praktik manajemen

8. memiliki akhlak yang baik, berwibawa, mampu berpendapat tentang ketentuan dan tujuan syariah

Sumber : Data Diolah

\subsection{PENELITIAN DAHULU}

Penelitian terkait audit syariah di Indonesia terbilang masih jarang. Penelitian yang ada lebih membahas mengenai kepatuhan syariah yang terfokus kepada Dewan Pengawas Syariah dan praktik audit syariah pada lembaga keuangan syariah, belum menyentuh kepada aspek kompetensi auditor syariah itu sendiri. Namun dari salah satu jurnal intenasional yang berasal dari Malaysia, ditemukan isu terkait kompetensi auditor syariah, akan tetapi dari beberapa penelitian, kompetensi auditor syariah dimasukan dalam aspek audit syariah tanpa diteliti secara terpisah. Diantara penelitian sebelumnya yang dimaksud, 
berasal dari Ali, et. al (2015) yang mengemukakan terkait isu-isu terkini mengenai kompetensi auditor syariah di Malaysia.

Selain itu, penelitian lain yang mengungkapkan mengenai isu terkait kompetensi auditor syariah secara parsial dapat ditemukan pada Kasim, Ibrahim \& Sulaiman (2009) yang meneliti empat isu terkait audit syariah dimana mereka menemukan ada gap antara apa yang diharapkan dengan realita praktek audit syariah dalam lembaga keuangan syariah di Malaysia, dalam hal kompetensi auditor syariah Kasim, Ibrahim \& Sulaiman (2009) menemukan bahwa hanya 5,9 \% dari responden yang memiliki kedua kulifikasi (akuntansi/auditing dan syariah) tersebut, sedangkan jumlah praktiksi audit syariah LKS di Malaysia yang menjadi responden sebanyak $69 \%$.

Oleh karena itu dari sekian isu audit syariah tersebut yang akan dibahas pada penelitian ini belum ditemukan pada penelitian sebelumnya. Adapun perbedaan yang mencolok dari penelitian ini terletak pada objek penelitian yang berbeda serta mengupas lebih mendalam mengenai isu dan tantangan auditor syariah di Indonesia.

\section{PEMBAHASAN}

Perkembangan entitas syariah seperti lembaga keuangan syariah menuntut adanya auditor sebagai penjamin kepercayaan masyarakat, juga memperluas ruang lingkup meliputi aspek syariah. Sehingga tuntutan kompetensi auditor juga harus memiliki standar profesional di bidang syariah.

Istilah auditor syariah dimunculkan untuk menyesuaikan dengan operasional entitas syariah. Tuntutan pemenuhan terhadap regulasi yang berlaku sekaligus prinsip syariah dalam operasional menghendaki proses audit tidak hanya dilakukan berdasarkan standar regulasi (Mardian, 2013, hal.179).

Menurut Haniffa (2010) auditor syariah tidak secara tegas dimaksudkan hanya untuk auditor independen yang tergabung dikantor akuntan publik melainkan pihak yang bisa menjalankan fungsi audit syariah. Pemain kunci yang terlibat dalam audit syariah dalam sebuah entitas dengan perannya masing-masing yaitu auditor eksternal, Dewan Pengawas Syariah dan auditor internal (hal. 2).

Setelah melakukan wawancara dengan pihak-pihak yang berkiprah dalam dunia audit syariah, maka dalam pembahasan ini auditor syariah di Indonesia yang dimaksud adalah hanya difokuskan kepada Dewan Pengawas Syariah (DPS). Karena pada dasarnya saat ini belum ada auditor syariah yang fungsinya sama dengan auditor independen pada lembaga keuangan konvensional di negara manapun yang ada hanya dewan pengawas syariah. Dewan pengawas syariah inilah yang berwenang melakukan audit syariah atau pemeriksaan kepatuhan lembaga keuangan syariah terhadap prinsip syariah di Indonesia. 


\subsection{ISU TERKAIT KOMPETENSI DEWAN PENGAWAS SYARIAH DI INDOESIA}

\subsubsection{Tidak Seimbangnya Kompetensi yang Dimiliki oleh Dewan Pengawas} Syariah Di Bidang Keuangan dan Akuntansi dengan Kompentensi Di Bidang Syariah

Lembaga keuangan syariah beroperasi dibawah platform yang berbeda yaitu dengan pandangan dunia Islam, saat itu pula lembaga keuangan syariah memerlukan jenis akuntansi dan audit yang baru. Pembeda antara audit syariah dengan audit konvensional salah satunya terletak pada aspek syariah yang menjadi landasan utama pelaksanaan audit syariah yang tidak diakomodir oleh audit konvensional (Khan, 1985).

Maka dari itu, pelaksanaan audit syariah pun tidak bisa dilakukan oleh auditor konvensional karena untuk menjadi auditor syariah diperlukan dua kualifikasi, bukan hanya harus memiliki kualifikasi yang dimiliki auditor konvensional pada umumnya seperti memiliki keterampilan dan pegetahuan dibidang akuntansi dan auditing, memahami standar akuntasi Internasioal yang diadopsi serta standar akuntasi dan auditing yang berlaku diwiayah nasional, memahami keuangan dan bisnis, memahami teori dan praktrek manajemen. Tetapi juga harus memiliki keilmuan dibidang syariah terkait prinsip dan hukum Islam, bidang syariah yaang dimaksud disini adalah utamanya mengenai fiqih muamalah serta mempunyai pemahaman tentang As-Sunnah dan ilmu fiqh seperti ushul figh dan memilki karateristik lain seperti memiliki akhlak yang baik, berwibawa, mampu berpendapat tentang ketentuan dan tujuan syariah (Mardian, 2015).

Sampai saat ini, permasalahan kompetensi auditor syariah yaitu terkait kurangnya pengetahuan baik dibidang syariah maupun dibidang akuntansi. Mayorias auditor syariah yang memiliki pengetahuan akuntansi cenderung tidak memiliki pengetahuan syariah dan sebaliknya. Masalah ini telah diperdebatkan sejak awal pembentukan keuangan Islam modern di tahun 1970-an (Khan, 1985).

Contohnya saja tergambarkan dari penelitian yang dilakukan oleh Kasim, Ibrahim, \& Sulaiman (2009) di Malaysia masih ditemukan ketimpangan (gap) antara kompetensi yang diharapkan dengan kompetensi aktual dari auditor syariah terkait kompetensi syariah dan akuntansi. Hanya $5,9 \%$ dari total responden yang memiliki kedua kompetensi tersebut pada saat bersamaan. Adapun keseluruhan responden tersebut mencerminkan $68 \%$ dari keseluruhan auditor syariah yang terdapat pada lembaga keuangan syariah di Malaysia. Hasil tersebut juga menunjukan adanya korelasi negatif antara orang-orang yang menguasai akuntansi dengan orang yang menguasai syariah. Artinya, semakin tinggi responden (auditor syariah) yang menguasai akuntansi maka semakin rendah penguasaannya terhadap syariah, begitupun sebaliknya. Hal ini menujukan pelaksanaan fungsi audit atau pemeriksaan belum berjalan maksimal. Dewan pengawas syariah relatif masih menjalankan fungsi konsultatif bukan fungsi pengawasan.

Ketimpangan kompetensi ini juga ditemukan di Bahrain seperti yang dilakukan oleh Hood dan Bucheery dikutip oleh Shafii, et. al (2013), 
penelitian tersebut menemukan bahwa ketidaksesuaian antara harapan dan realita yang terjadi karena belum memadainya pemahaman auditor syariah yang terlihat dari audit syariah yang hanya difungsikan sebagai pelengkap dari audit keuangan. Selain itu, juga belum ditemukan opini dari audit syariah seperti layaknya audit keuangan dari auditor independen.

Penelitian lain juga dilakukan oleh Mahzan dan Yahya dikutip oleh Ali, et.al (2015) yang melakukan survey kepada 158 auditor internal lembaga keuangan syariah. Hasil dari penelitian menunjukan bahwa 39\% responden memiliki pengalaman kerja 10-20 tahun didunia perbankan umum dan hanya $6 \%$ yang memiliki pengalaman kerja 10-20 tahun didunia perbankan dan keuangan syariah. Hal ini sangat mengkhawatirkan karena $76 \%$ audit internal tersebut tidak memiliki kualifikasi syariah, keuangan dan perbankan syariah tetapi mereka telah melakukan audit syariah.

Di Indonesia sendiri, penelitian yang dilakukan oleh Kasim, et. al (2013), diketahui bahwa terjadi lack pada aspek kualifikasi auditor syariah. Tidak semua dewan pengawas syariah memahami mekanisme audit syariah, karena di Indonesia rata-rata perbandingan dua kualifikasi yang dimiliki dewan pengawas syariah saat ini belum seimbang, rata-rata penguasaan ilmu syariahlah yang lebih tinggi. Dan belum maksimalnya peran auditor internal yang dapat bersinergi dengan dewan pengawas syariah melalui internal syariah review belum dimiliki oleh mayoritas lembaga keuangan syariah.

Menurut Nuryadi (2015), latar belakang komposisi dewan pengawas syariah beragam, yaitu ada yang berasal dari backgraund syariah seperti dari anggota Dewan Syariah Nasional dan dari tokoh ulama, ada juga yang berasal dari backgraund praktisi atau bankir seperti dari drektur utama bank konvensional, manajer perusahaan asuransi konvensional dan yang lainnya. Romansyah (2015) mengemukakan bahwa auditor syariah yang berasal dari dewan syariah nasional mereka hanya memiliki pemahaman syariah termasuk fiqh muamalah, sedangkan auditor syariah yang berasal dari praktisi mereka lebih mengerti teknis audit tetapi mereka tidak memahami fiqh dan fatwa.

Didukung dengan data yang diperoleh dari laporan tahunan perbankan syariah tahun 2014 yaitu, Bank Syariah Mandiri, Bank Muamalat Indonesia, Bank Rakyat Indonesia Syariah, Bank Mega Syariah, Bank Negara Indonesia Syariah, Bank Central Asia Syariah dan Panin Bank Syariah menunjukan bahwa jumlah dewan pengawas syariah di perbankan syariah tersebut yang berlatarbelakang syariah adalah $84,2 \%$, sedangkan $15,8 \%$ lainnya berlatarbelakang akuntansi dan keuangan.

Menurut Mardian (2015) adanya ketimpangan kompetensi auditor syariah di Indonesia dikarenakan oleh kehadiran entitas syariah di Indonesia tergolong masih baru, sehingga sumber daya manusia belum mampu memenuhi kebutuhan industri saat ini sehingga dewan pengawas syariah banyak direkrut dari background ulama dan dari faktor kharisma serta kepopulerannya di tengah masyarakat, bukan karena keilmuannya di bidang akuntansi, keuangan dan syariah. Mardian (2015) menambahkan mayoritas dewan pengawas syariah di Indonesia belum memenuhi dua kompetensi yang harus dipenuhi, karena tidak adanya hukum atau regulasi yang mengikat yang 
megharuskannya dewan pengawas syariah memiliki kompetensi tersebut, sehingga kompetensi yang harus dimiliki tergantung oleh masing-masing individu dewan pengawas syariah itu sendiri.

Menurut Yasni (2016), untuk menjadi seorang dewan pengawas syariah memang diperlukan kedua kompetensi tersebut dalam waktu bersaaaan, karena untuk memastikan bahwa opersional lembaga keuangan syariah sesuai dengan syariah dibutuhkan pemahaman dibidang syariah dan dalam melakukan sampling audit dibutuhkan pemahaman dibidang keuangan secara umum dan akuntansi.

Pandangan berbeda terkait isu di atas disampaikan oleh Tanjung (2015), dilihat dari pengertian DPS menurut UU No. 21 tahun 2008 tentang perbankan syariah. Dalam pasal 32 ayat 1 Undang-Undang tersebut menyebutkan bahwa: (a) Dewan Pengawas Syariah merupakan badan yang dibentuk di Bank Syariah dan Bank Umum Konvensional yang memiliki UUS, (b) Dewan Pengawas Syariah sebagaimana dimaksud pada ayat (1) diangkat oleh Rapat Umum Pemegang Saham atas rekomendasi Majelis Ulama Indonesia, (c) Dewan Pengawas Syariah sebagaimana dimaksud pada ayat (1) bertugas memberikan nasihat dan saran kepada direksi serta mengawasi kegiatan Bank agar sesuai dengan Prinsip Syariah.

Sedangkan peran dan fungsi DPS menurut Surat Keputusan DSN MUI No. Kep-98/MUI/III/2001 tentang Susunan Pengurus DSN MUI Masa Bhakti Th. 2000-2005 yang paling utama adalah (a) melakukan pengawasan secara periodik pada lembaga keuangan syariah, dan (b) melaporkan perkembangan produk dan operasional lembaga keuangan syariah yang diawasinya kepada DSN sekurang-kurangnya dua kali dalam satu tahun anggaran.

Maka Tanjung (2015) berpendapat bahwa kompetensi yang harus dimiliki oleh seorang auditor syariah (DPS) tidak harus memiliki kualifikasi yang dimiliki auditor konvensional pada umumnya seperti memiliki keterampilan dan pegetahuan dibidang akuntansi dan auditing, memahami standar akuntasi Internasioal yang diadopsi serta standar akuntasi dan auditing yang berlaku diwiayah nasional, memahami keuangan dan bisnis, memahami teori dan praktrek manajemen. Akan tetapi cukup memiliki keilmuan di bidang syariah terkait prinsip dan hukum Islam. Bidang syariah yang dimaksud disini adalah utamanya mengenai fiqih muamalah serta mempunyai pemahaman tentang As-Sunnah dan ilmu fiqh seperti ushul fiqih dan juga praktik dan operasional entitas syariah serta proses bisnis yang dijalankan entitas tersebut ditambah dengan karakteristik yang mendukung seperti berakhlak baik dan memiliki komitmen terhadap ekonomi Islam.

Hal tersebut didukung oleh pernyataan Romansyah (2015) dimana untuk saat ini dewan pengawas syariah hanya dituntut memiliki pemahaman syariah dan proses bisnis suatu entitas karena tugas dewan pengawas syariah yaitu bertugas memberikan nasihat dan saran kepada direksi serta mengawasi kegiatan lembaga keuangan syariah agar sesuai dengan prinsip syariah belum masuk kepada audit keuangan. Akan tetapi jika dewan pengawas syariah memiliki kompetensi syariah dan keuangan dalam bersamaan itu akan lebih baik. 
Akan tetapi isu mengenai ketidakseimbangan kompetensi akuntansi dan keuangan dengan kompetensi syariah yang harus dimiliki oleh auditor syariah tersebut di Indonesia telah dijembatani dengan cara setiap entitas syariah harus memiliki minimal dua orang dewan pengawas syariah dan melakukan koordinasi antara dewan pegawas syariah yang berasal dari background syariah dan memiliki kompetensi dibidang tersebut dengan dewan pegawas syariah yang berasal dari background akuntansi dan keuangan dan memiliki kompetensi dibidang tersebut pula. Sehingga isu tersebut tidak terlalu krusial (Nuryadi, 2015). Menurut Yasni (2015) bahwa dalam menghadapi gap diatas auditor syariah harus mampu memahami Dewan Standar Akuntansi Keuangaan Syariah dan Pedoman Standar Akuntansi Syariah yang berlaku di Indonesia.

\subsubsection{Sertifikasi Dewan Pengawas Syariah di Indonesia Belum Optimal}

Sertifikasi auditor syariah dapat menjadi sarana untuk mencerminkan kemahiran auditor syariah dalam melakukan audit syariah dan sikap yang profesional dan kompeten yang dimiliki oleh auditor syariah. Maka dari itu, sertifikasi audit syariah harus dilaksanakan di lembaga keuangan syariah. Sertifikasi auditor syariah tidak hanya sebagai bukti pengetahuan dan prestasi para auditor syariah melainkan merupakan jaminan dan akuntabilitas kepada para stakeholder bahwa auditor syariah profesional dan siap untuk memenuhi tantangan terkait audit syariah. Sertifikasi audit syariah juga akan memperkaya para auditor syariah dengan pengalaman pendidikan, keahlian dalam bidang syariah dan audit, mendapatkan informasi, dan tools bisnis yang dapat diterapkan dalam organisasi atau lingkungan bisnis (Shafii, et. al, 2014).

Untuk profesi tertentu, sertifikasi diperlukan untuk memastikan kompetensi dan keahlian di bidang tertentu. Misalnya, akuntan dan auditor diwajibkan oleh hukum untuk disertifikasi sebagai Certified Public Accountant (CPA), atau Certified Internal Auditors (CIA). Ketika audit syariah memerlukan keterampilan dan kemampuan khusus, maka tuntutan kompetensi auditor juga harus memiliki standar profesional di bidang syariah. Oleh karena itu auditor syariah pun harus memiliki sertifikasi auditor syariah atau Certified Sharia Auditors untuk memastikan bahwa auditor syariah mampu melakukan audit serta memastikan kepatuhan syariah. Program sertifikasi audit syariah dapat memenuhi permintaan industri pada tingkat pengetahuan syariah dan keuangan, kompetensi dan kualifikasi sebagai auditor syariah. Maka dari itu diperlukan pelaksanaan sertifikasi dibidang audit syariah (Yasni, 2016).

Di Timur Tengah, Accounting and Auditing of Islamic Financial Institutions (AAOIFI) telah memulai sertifikasi untuk penasihat dan auditor syariah. Sertifikasi yang dikeluarkan oleh AAOIFI juga dikenal sebagai Certified Sharia Adviser and Auditors (CSAA). Program CSAA dirancang untuk membekali calon penasihat dan auditor syariah dengan pemahaman dan keterampilan profesional teknis yang diperlukan pada kepatuhan syariah dan proses review untuk perbankan dan industri keuangan syariah 
internasional. Program CSAA meliputi pembelajaran teknis yang penting untuk kepatuhan syariah dan proses review dan prosedur seperti standar AAOIFI pada produk dan praktik keuangan syariah, standar tata kelola AAOIFI pada kepatuhan syariah dan proses review, perbankan syariah dan pengawasan keuangan, dan juga aplikasi syariah dan untuk praktik perbankan dan keuangan syariah. Setelah mengikuti program CSAA ini diharapkan auditor dan penasihat syariah mampu memastikan kepatuhan lembaga keuangan syariah sesuai dengan fatwa Dewan Syariah Nasional (Shafii, et. al, 2014).

Di Malaysia saat ini, tidak ada badan profesional atau lembaga yang menawarkan sertifikasi audit syariah. Namun, ada beberapa lembaga yang memberikan pelatihan untuk auditor syariah seperti CERT, Redmoney dan AsiaBIS. Pelatihan ini dilakukan untuk memenuhi permintaan industri bahwa auditor syariah harus dilengkapi dengan keterampilan dan pengetahuan yang diperlukan untuk melakukan audit syariah.

Sama halnya kebutuhan sertifikasi auditor syariah di Malaysia, di Indonesia pun sertifikasi untuk auditor syariah belum belum menjadi suatu hal yang wajib. Hal ini didukung oleh pernyataan Mardian (2015) di Indonesia awalnya telah ada wacana sertifikasi yang mengikat untuk mengukur keseragaman kompetensi yang dimiliki oleh auditor syariah yang dibuat oleh Majelis Ulama Indonesia bersama Bank Indonesia. Namun kabar baik tersebut tidak disambut baik oleh para dewan pengawas syariah tersebut dikarenakan adanya resistensi (tidak mau mengikuti), sehingga tidak menjadi suatu hal yang wajib. Sampai saat ini program itu masih ada tetapi tidak diwajibkan. Padahal seharusnya sertifikasi itu sifatnya memaksa (wajib) seperti halnya peraturan yang dilakukan oleh auditor konvensional. Dimana seseorang tidak boleh melakukan audit jika belum mendapatkan sertifikasi profesi seperti Certified Public Accountant (CPA).

Romansyah (2015) mendukung penyataan Mardian (2015) bahwa isu terkait kompetensi auditor syariah salah satunya yaitu belum ada sertifikasi yang mengikat yang wajib diikuti oleh auditor syariah. Beliau menabahkan bahwa Ikatan Akuntan Publik Indonesia (IAPI) baru merumuskan standar atau sertifikasi auditor syariah. Wacananya yaitu auditor independen harus lulus dan memiliki serftifikasi auditor syariah jika mereka ingin mengaudit lembaga keuangan syariah, akan tetapi hal tersebut belum final. Selain itu, dari sisi dewan pengawas syariah yang diharuskan oleh Otoritas Jasa Keuangan untuk tidak hanya mengikuti fit and proper test melainkan mengikuti sertifikasi juga, akan tetapi dari fit and proper test saja masih banyak ditemukan dewan pengawas syariah yang belum memenuhi kompetensi yang diharapkan untuk menjadi dewan pengawas syariah apa lagi jika mereka mengikuti ujian sertifikasi sudah dipastikan banyak yang berguguran.

Romansyah (2015) menambahkan bahwa jika anggota dewan pengawas syariah hanya melakukan fit and proper test saja, maka tidak akan terukur kompetensinya, karena fit and proper test tidak termasuk dalam sertifikasi. Seharusnya dewan pengawas syariah mengikuti tiga level 
sertifikasi. Level sertifikasi pertama merupakan pengenalan industri syariah sesuai dengan jenis dan bidangnya, level kedua adalah tahap intermediet, di mana ilmu pengawasan terhadap kepatuhan syariah akan diberikan seperti cara membaca dan menyiapkan check list audit pengawasan syariah. Level terakhir adalah advance, pada level ini dewan pengawas syariah diajarkan metode penyusunan opini syariah. Karena apabila dewan pengawas syariah telah mengikuti dan mendapatkan sertifikat di semua level, maka mereka bisa menerapkan pengawasan dengan baik, bukan sekadar tahu soal hukum riba dan halal pada produk syariah saja.

Isu sertifikasi yang belum optimal tersebut didukung oleh pernyataan Adiwarman Karim yang mengungkapkan sekitar lebih dari 200 Dewan Pengawas Syariah di Indonesia baru memperoleh sertifikasi pada level dasar (level I basic). Padahal Dewan Pengawas Syariah tersebut ditempatkan pada industri perbankan dan asuransi syariah. Saat ini, Adiwarman menyebut sebanyak 167 orang Dewan Pengawas Syariah yang bergerak di industri perbankan syariah serta lebih dari 40 orang Dewan Pengawas Syariah di asuransi syariah telah memperoleh sertifikasi syariah dari DSN-MUI. (Arianti, 2013).

Menurut Yasni (2016), adanya kebutuhan akan peningkatan kompetensi ini seharusnya didukung oleh sertifikasi auditor syariah yang sifatnya mengikat (wajib) agar auditor syariah dapat meningkatkan kualitas dirinya.

3.1.3 Minimnya Lembaga Pendidikan dan Pelatihan yang Menyediakan Kurikulum Akuntansi/ Auditing Syariah Sehingga Dewan Pengawas Syariah yang Ada Masih Terbatas

Berdasarkan UU No. 12 tahun 2012 disebutkan bahwa pendidikan tinggi dengan kewajiban tridharma perguruan tingginya memiliki tujuan untuk menghasilkan lulusan yang menguasai ilmu pengetahuan dan teknologi untuk memenuhi kepentingan nasional dan meningkatkan daya saing bangsa. Pendidikan tinggi tersebut dapat dilaksanakan melalui pendidikan akademik, pendidikan vokasional dan pendidikan profesi. Pendidikan tinggi merupakan institusi penyelenggara tertinggi yang melahirkan sumber daya manusia yang siap memberikan kontribusi pada negara masyarakat dan negara (Mardian, 2013).

Mardian (2013) menambahkan munculnya berbagai macam jurusan dan konsentrasi di perguruan tinggi banyak didorong oleh tingkat kebutuhan sumber daya manusia di industri. Begitu juga dengan paradigma link and match kurikulum dengan kompetensi yang dibutuhkan industri. Program studi akuntansi syariah, perbankan syariah dan sejenisnya adalah bentuk respon perguruan tinggi terhadap perkembangan industri lembaga keuangan syariah yang ada. Seperti yang disebutkan sebelumnya, estimasi Bank Indonesia terhadap sumber daya manusia yang dibutuhkan dalam pengembangan perbankan syariah di Indonesia mencapai sekitar 50.000 orang pada 2015 dan mencapai sekitar 400.000 orang pada tahun 2020 . 
Dunia pendidikan baik formal atau informal memiliki peran strategis untuk menyiapkan auditor syariah. Ditambah lagi, audit syariah ini dapat dimasukkan kedalam kurikulum perkuliahan sehingga menghasilkan lulusan ganda yaitu dibidang akuntansi dan syariah yang menimbulkan internalisasi kompetensi akuntansi dan syariah (Kasim \& Sanusi, 2013, hal. 15-16). Selain itu dalam perkuliahan juga dapat dilengkapi dengan pembekalan keterampilan teknis audit. Dikuatkan oleh Yacoob \& Donglah (2012) bahwa keterlibatan sarjana syariah dinilai sangat penting untuk turut mempromosikan audit syariah (hal. 237-238).

Sementara itu, lembaga informal seperti lembaga pelatihan dapat memberikan pemahaman yang mendalam tentang wawasan dan keterampilan akuntansi dan syariah kepada tingkat professional. Artinya, lembaga informal berperan dalam pemenuhan kebutuhan dalam jangka pendek dan lembaga formal dalam jangka panjang (Mardian, 2013).

Di Pakistan, Hussain dan Parker meneliti terkait isu-isu seleksi dan pelatihan penasihat syariah pada lembaga keuangan syariah, mereka menemukan adanya keterbatasan penasihat syariah yang kompeten baik dalam jumlah kualitas dan kuantitas yang dapat bekerja untuk beberapa lembaga keuangan syariah (Ali, et. al, 2015).

Begitupun di Malaysia, hanya ada satu perguruan tinggi yang menawarkan auditing syariah sebagai program studi, yaitu di Islamic Science University of Malaysia (USIM). Selain itu juga, USIM menawarkan mata kuliah fiqh muamalah dan audit syariah untuk mahasiswa akuntansi mereka. Namun tidak semua mahasiswa akuntansi USIM tertarik untuk menjadi bagian dari tenaga kerja perbankan syariah hal ini akan menyebabkan Malaysia kekurangan auditor syariah yang baru (fresh graduate). Beruntungnya, di Malaysia telah ada lembaga pelatihan untuk mengembangkan auditor yang kompeten seperti Institute of Banking and Finance Institution (IBFIM), International Centre for Education Islamic Finance (INCEIF) Centre for Research and Training (CERT) dan REDmoney. IBFIM contohnya, telah mengembangkan sertifikasi kualifikasi di lembaga keuangan syariah atau disebut dengan Certified Qualification in Islamic Finance (CQIF) yang terdiri dari tiga level, yaitu level inti, menengah dan level lanjutan (Ali, et. al, 2015).

Di Indonesia dalam penelitian yang dilakukan oleh Kasim, et. al (2013), diketahui bahwa lembaga pendidikan yang mencetak akuntan syariah sangatlah minim yang berimabas pada praktisi auditor syariah yang terbatas. Hal ini juga menjadi salah satu penyebab terbatasnya lingkup audit syariah saat ini karena minimnya praktisi auditor syariah yang memiliki kompetensi yang mumpuni untuk menjalankan pemerikasaan audit syariah secara komprehensif. Menurut Mardian (2015) hanya terdapat enam perguruan tinggi yang menyediakan program studi akuntansi syariah, tiga dari perguruan tinggi swasta yaitu STEI SEBI, STEI TAZKIA, dan STEI Bina Cipta Madani, serta tiga dari perguruan tinggi negeri yaitu IAIN Surakarta, UIN Sunan Kalijaga dan UIN Walisongo Semarang. Dan lembaga pelatihan seperti IAI Knowledge Centre yang menyediakan pelatihan akuntansi syariah 
juga tergolong masih jarang. Sedangkan di level profesi, hingga tahun 2015 hanya sekitar 54 orang yang memiliki Sertifikasi Akuntansi Syariah (SAS) yang dikeluarkan oleh Ikatan Akuntan Indonesia (Ikatan Akuntan Indonesia, 2015). Dapat terlihat bahwa media untuk menghasilkan sumber daya manusia yang berkualifikasi juga masih minim. Selanjutnya, menurut Yasni (2016) jumlah dewan pengawas syariah untuk saat ini tidak lebih dari 400 orang dan untuk ruang lingkup Indonesia yang begitu luas dengan perkembangan industri yang begitu cepat, jumlah dewan pengawas syariah tersebut masih kurang untuk dapat mengakomodir kebutuhan industri. Hal ini mencerminkan kuantitas auditor syariah yang kompeten yang dibutuhkan relatif belum memadai. Dilihat dari sisi kuantitas auditor akan terus mengalami gap yang semakin timpang apabila tidak mampu merespon perkembangan lembaga keuangan syariah kedepannya.

Menurut Mardian (2015) masih sedikitnya lembaga pendidikan atau perguruan tinggi yang menyediakan kurikulum akuntansi ataupun auditing syariah karena pihak lembaga pendidikan pun sulit mencari dosen yang kompeten terkait ilmu akuntansi syariah. Selain itu, walaupun telah ada lembaga pendidikan atau perguruan tinggi yang telah memulai memiliki akuntansi syariah dalam kurikulumnya, akan tetapi alumni mereka belum tentu mudah masuk menjadi anggota dewan pengawas syariah. Dibutuhkan waktu selama 10-15 tahun agar mereka dapat berkiprah dalam dunia auditor syariah.

Karena kurangnya auditor syariah yang dapat memenuhi kebutuhan industri yang tergambar dari sedikitnya jumlah auditor syariah di Indonesia mengakibatkan rangkap jabatan dilakukan oleh dewan pengawas syariah dimana auditor syariah bekerja pada beberapa lembaga keuangan syariah pada periode yang sama. Di Indonesia memang diperbolehkan auditor syariah bekerja untuk 4-5 lembaga keungan syariah, namun rangkap jabatan pada lebih dari satu institusi lembaga keuangan syariah dapat memicu konflik kepentingan dan dapat memungkinkan mengganggu obyektivitas dalam menjalankan pengawasan syariah. Romansyah (2015) menambahkan karena kurangnya auditor syariah juga bank syariah memiliki kecenderungan untuk memilih tokoh atau pakar syariah yang populer untuk menjadi calon dewan pengawas syariah dengan tujuan agar kepercayaan masyarakat terhadap kesyariahan produk dan kegiatan bank syariah meningkat karena faktor popularitas dewan pengawas syariah sebagai salah satu tokoh/pakar syariah.

\subsection{TANTANGAN TERKAIT KOMPETENSI DEWAN PENGAWAS SYARIAH DI INDONESIA}

\subsubsection{Upgrade Kompetensi Dewan Pengawas Syariah}

Dilihat dari isu pertama yang telah dijelaskan pada subbab sebelumnya, terkait tidak seimbangnya kompentensi yang dimiliki oleh auditor syariah baik dibidang keuangan dan akuntansi dengan kompentensi dibidang syariah. Dimana melakukan wawancara dengan responden yang hasilnya para responden mengemukakan bahwa di Indonesia ini latar belakang dewan 
pengawas syariah beragam, ada yang berasal dari background praktisi (bankir) dan dari berasal background ulama. Responden mengemukakan juga, bahwa dewan pengawas syariah yang berasal dari dewan syariah nasional (background ulama) mereka cenderung hanya memiliki pemahaman syariah saja, sedangkan dewan pengawas syariah yang berasal dari praktisi (bankir) lebih mengerti akuntansi, keuangan, teknis audit, tetapi mereka tidak mengerti fiqh dan fatwa.

Maka dari itu, tantangan pertama yang dihadapi terkait kompetensi auditor syariah di Indonesia yaitu kompetensi yang dimiliki harus diupgrade agar produk yang berkembang saat ini tidak keluar dari aturan dan prinsip syariah. Upgrade kompetensi ini dengan cara membankirkan ulama dan mengulamakan bankir. Dimana dewan pengawas syariah yang berasal dari background praktisi (bankir) diikutkan training-training atau pelatihan terkait syariah. Sedangkan dewan pengawas syariah yang berasal dari background ulama diikutkan training Pendidikan Profesi Lanjutan (PPL) yang ditawarkan oleh Ikatan Akuntan Indonesia.

Hal ini bertujuan agar dewan pengawas syariah dapat memenuhi kompetensi yang diperlukan oleh industri yaitu pemahaman terhadap akuntansi dan keuangan dengan pemahaman terhadap syariah dalam waktu bersamaan. Akan tetapi, tidak semua dewan pengawas syariah merasa perlu untuk mengupgrade kemampuannya. Contohnya saja, masih banyak dewan pengawas syariah tersebut yang paham syariah tidak merasa perlu memahami ilmu yang lain karena mereka beranggapan bahwa ilmu syariah adalah ilmu yang paling pure. Padahal pada kenyataannya menjadi seorang auditor syariah atau dewan pengawas syariah idealnya memiliki pemahaman dibidang akuntansi, keuangan dan syariah, hal ini menjadi tantangan yang nyata yang harus dihadapi. Selain itu, dewan pengawas syariah harus dapat berinovasi terhadap fatwa dan produk-produk baru serta tidak hanya bertugas sebagai stamper saja, melainkan harus menemukan fatwa terhadap isu produk yang sedang berkembang. Tantangan tersebut sangat urgen untuk saat ini, karena perkembngan industri syariah di Indonesia saat ini sudah hampir disemua lini. Sedangkan menemukan sumber daya manusia fresh graduate yang berkompeten jauh dari kata maksimal.

\subsubsection{Kerjasama Antara DSN-MUI Dengan OJK Dalam Menciptakan Sertifikasi Dewan Pengawas Syariah yang Wajib}

Melihat kebutuhan sertifikasi untuk era saat ini dan pentingnya sertifikasi auditor syariah untuk dapat mengukur profesionalitas dan kemahiran dalam melakukan audit syariah, ditambah dengan isu yang ada bahwa di Indonesia para dewan pengawas syariah tidak bersedia melakukan tahapan sertifikasi, dan sertifikasi sifatnya masih bukan suatu hal yang wajib. Padahal idealnya sertifikasi itu sifatnya memaksa seperti halnya sertifikasi pada profesi lain.

Tantangan dari isu diatas yaitu kerjasama antara DSN-MUI dengan OJK dalam menciptakan sertifikasi auditor syariah yang wajib. DSN-MUI bekerjasama dengan OJK agar seluruh dewan pengawas syariah tidak hanya mengikuti fit and proper test saja melainkan mengikuti tiga level sertifikasi. 
Yaitu level inti, intermediary, dan advance. Dengan sertifikasi bagi para dewan pengawas syariah yang bersifat memaksa, maka hal tersebut menjadi disiplin industri yang mengharuskan dewan pengawas syariah memiliki kompetesi yang ditetapkan oleh DSN-MUI dengan OJK tersebut dan ada tuntutan tersendiri bagi individual dewan pengawas syariah tersebut untuk mengembangkan diri. Sertifikasi pula menjadi alat ukur keseragaman kompetensi dewan pengawas syariah sehingga nantinya dewan pengawas syariah yang berkompetenlah yang berhak melakukan audit syariah pada lembaga keuangan syariah.

\subsubsection{Lembaga Pendidikan Mampu Memenuhi Kebutuhan Industri Terkait Dewan Pengawas Syariah}

Pentingnya lembaga pendidikan baik formal atau informal yang memiliki peran strategis untuk menyiapkan auditor syariah dan dapat memberikan pemahaman yang mendalam tentang wawasan dan keterampilan akuntansi dan syariah kepada tingkat professional menyebabkan kebutuhan akan lembaga pendidikan untuk memenuhi sumber daya manusia dalam industri. Namun lembaga pendidikan dan pelatihan yang menyediakan kurikulum akuntansi/ auditing syariah yang masih minim menimbulkan auditor syariah yang ada masih terbatas.

Tantangan dari isu tersebut yaitu lembaga pendidikan harus mampu memenuhi kebutuhan industri terkait auditing syariah. Idealnya lulusan akuntansi saat ini telah dibekali dengan pengetahuan syariah sebelum mereka memulai bekerja di lembaga keuangan syariah agar memperluas skills dan pengetahuan audit dengan syariah serta kompetensinya. Sedangkan menurut El Razik (2009) Karena pada dasarnya auditing syariah dengan auditing konvensional berbeda, hal ini mencerminkan bahwa ada tantangan tersendiri untuk lembaga pendidikan agar lulusan mereka yang menjadikan profesi auditor syariah sebagai prospek kerja untuk memahami standar adopsi yang berbeda dalam dunia akuntansi syariah dengan akuntansi konvensional yang telah diadopsi oleh berbagai negara-negara muslim dengan standar akuntansi syariah yang berbeda-beda pula bahwa untuk lulusan keuangan syariah, mereka harus memiliki pemahaman terkait Standar Akuntansi Internasional serta standar yang diadopsi oleh negara-negara muslim lain jika mereka ingin bekerja di negara lain yang telah menerapkan audit syariah. (hal. 3).

Di Indonesia tantangan dalam lembaga pendidikan harus mampu memenuhi kebutuhan industri terkait auditing syariah. Pesatnya pertumbuhan industri keuangan syariah menyebabkan kebutuhan akan sumber daya manusia termasuk dewan pengawas syariah meningkat pula. Maka lembaga pendidikan harus mampu menciptakan fresh graduate yang berkualitas dan berkompeten untuk dewan pengawas syariah. Selain itu, lembaga pendidikan harus mampu memperbaiki atau mengarahkan kurikulum yang ada untuk menekankan ilmu audit syariah, kemudian menggunakan pendekatan teori ke praktik agar dapat berkontribusi dalam hal pemenuhan supply dimasa yang akan datang untuk profesi auditor syariah. 


\section{SIMPULAN}

Dari hasil analisis dan pembahasan dengan menggunakan metode studi kepustakaan (library research) dan menggabungkan dengan wawancara responden terkait isu dan tantangan kompetensi Dewan Pengawas Syariah di Indonesia. Maka kesimpulan dari penelitian ini, adalah sebagai berikut:

1. Isu kompetensi dewan pengawas syariah di Indonesia

Terdapat tiga poin penting yang menjadi isu kompetensi dewan pengawas syariah di Indonesia berdasakan studi kepustakaan (library research) dan hasil wawancara responden. Tiga isu tersebut adalah 1) Tidak seimbangnya kompetensi yang dimiliki oleh dewan pengawas syariah di bidang keuangan dan akuntansi dengan kompentensi di bidang syariah, 2) Sertifikasi dewan pengawas syariah di Indonesia belum optimal, 3) Lembaga pendidikan dan pelatihan yang menyediakan kurikulum akuntansi/ auditing syariah sehingga dewan pengawas syariah yang Ada masih terbatas.

2. Tantangan kompetensi dewan pengawas syariah di Indonesia

Berdasarkan isu diatas dan berdasakan studi kepustakaan (library research) dan hasil wawancara responden, maka hal-hal yang menjadi tantangan terkait kompetensi auditor syariah di Indonesia adalah 1) Upgrade kompetensi dewan pengawas syariah, 2) Kerjasama antara DSN-MUI dengan OJK dalam menciptakan sertifikasi dewan pengawas syariah yang wajib, 3) Lembaga pendidikan mampu memenuhi kebutuhan Industri terkait dewan pengawas syariah.

\section{DAFTAR PUSTAKA}

AAOIFI. (2010). Shariah Standard for Islamic Financial Institution. Bahrain: AAOIFI.

Akbar, T. (2015). Mengurai Permasalahan Audit Syariah di Perbankan Syariah Indonesia dengan Menggunakan Analytic Network Process $(A N P)$. Depok: STEI SEBI.

Ali, N. A. M., Mohamed, Z. M., Shahimi, S., \& Shafii, Z. (2015). Competency of Shariah Auditors in Malaysia: Issues and Challenges. Journal of Islamic Finance, 4(1), 22-30.

Arianti, F. (2013, Juni 27). Ratusan Dewan Pengawas Syariah RI cuma Bersertifikasi Level Dasar. Dipetik Januari 05, 2016, dari Liputan6.com: http://bisnis.liputan6.com/read/623948/ratusan-dewanpengawas-syariah-ri-cuma-bersertifikat-level-dasar

DSN MUI. (2001). Surat Keputusan DSN MUI: Susunan Pengurus DSNMUI Masa Bakti thn. 2000-2005. Jakarta: DSN-MUI. 
El Razik, A. A. (2009). Challenges of IFRS in the Islamic Accounting World: Case of Middle Eastern Countries. Scientific Bulletin-Eco Sciences, 8(14), 1-5.

Haniffa, R. (2010). Islamic Financial Instrument and Market. London: Blomsboory Information Ltd.

Ikatan Akuntan Indonesia. (2015). Pemegang SAS. Dipetik Desember 22, 2015, dari Sertifikasi Ikatan Akuntan Indonesia (Sertifikasi IAI): http://iaisertifikasi.blogspot.com/p/pemegangcpsak.html?view $=$ snapshot

Kasim, N., \& Sanusi, Z. M. (2013). Emerging issues for auditing in Islamic Financial Institutions: Empirical evidence from Malaysia. IOSR Journal of Business and Management, 8(5), 10-17.

Kasim, N., Ibrahim, M., Hameed, S., \& Sulaiman, M. (2009). Shariah auditing in Islamic financial institutions: exploring the gap between the" desirable" and the" actual". Global Economy \& finance journal, 2(2), 127-137.

Kasim, N., Sanusi, Z. M., Mutamimah, T., \& Handoyo, S. (2013). Assessing the current practice of Auditing in Islamic Financial Institutions in Malaysia and Indonesia. International Journal of Trade, Economics and Finance, 4(6), 414.

Khan, M. A. (1985). Role of the Auditor in an Islamic Economy. Journal of research in Islamic economics, 3(1), 31-42

Kreitner, R., \& Kinicki, A. (2003). Perilaku Organisasi, Edisi Bahasa Indonesia. Jakarta: Salemba Empat.

Mardian, S. (2013). Auditor Syariah: Lulusan Syariah atau Lulusan Akuntansi. Kordinat Jurnal Komunikasi Antar Perguruan Tinggi Agama Islam Swasta, 8(1), 179-198.

Mardian, S. (2015, Desember 17). Isu dan tantangan kompetensi auditor syariah di Indonesia. (N. Farhana, Pewawancara)

Nuryadi, A. (2015, Desember 19). isu dan tantangan kompetensi auditor syariah di Indonesia. (N. Farhana, Pewawancara)

OJK. (2013). Laporan Perkembangan Keuangan Syariah. Jakarta: Otoritas Jasa Keuangan.

OJK. (2015). Statistik Perbankan Syariah. Jakarta: Otoritas Jasa Keuangan .

Romansyah, D. (2015, Desember 21). Isu dan tantangan kompetensi auditor syariah di Indonesia. (N. Farhana, Pewawancara)

Shafii, Z., Abidin, A. Z., Salleh, S., Jusoff, K., \& Kasim, N. (2013). Post Implementation of Shariah Governance Framework: The Impact of Shariah Audit Funtion Towards the Role of Shariah Committe. Jurnal 
of Scientific Research 13 (Research in Contemporary Islamic Finance and Wealth Management), 7-11.

Shafii, Z., Salleh, S., Zakaria, N., Hanefah, M. M., Ali, N. A. M., \& Yunanda, R. A. (2014). Shariah Audit Certification Contents: Views of Regulators, Shariah Committee, Shariah Reviewers and Undergraduate Students. International Journal of Economics and Finance, 6(5), 210.

Spencer, L. M., \& Spencer, S. M. (1993). Competence Work: Model for Superior Performance. John Wiley and Sons, Inc.

Sultan, S. A. (2007). A Mini Shari'ah Audit for The Islamic Financial Institutions-A Primer (Pocket Size). Kuala Lumpur: CERT.

Tanjung, H. (2015, Desember 20). Isu dan tantangan kompetensi auditor syariah di Indonesia. (N. Farhana, Pewawancara)

Yaacob, H., \& Donglah, N. K. (2012). Shari'ah audit in Islamic financial institutions: the postgraduates' perspective. International Journal of Economics and Finance, 4(12), 224.

Yasni, M. G. (2016, Januari 27). Isu dan tantangan kompetensi auditor syariah di Indonesia. (N. Farhana, Pewawancara) 
